\title{
ESCRITA ACADÊMICA E DESENVOLVIMENTO DE AUTORIA NA FORMAÇÃO DE PROFESSORES VIA EAD: AS UNIVERSIDADES ESTÃO PREPARADAS? ${ }^{41}$
}

\author{
ACADEMIC WRITING AND DEVELOPMENT OF AUTHORSHIP \\ IN TEACHER TRAINING VIA DISTANCE EDUCATION: ARE THE \\ UNIVERSITIES PREPARED?
}

Dorotea Frank Kersch ${ }^{42}$

Fernando César dos Santos ${ }^{43}$

\begin{abstract}
RESUMO: A demanda crescente por cursos de formaçăo de professores ocasionou o crescimento dos cursos de licenciatura a distância, os quais se tornaram o tipo de graduaçăo em maior número nessa modalidade de ensino. Dentro deste grupo, o curso de Pedagogia é o que conta com maior número de inscritos. Nosso objetivo é identificar as concepçóes de trabalho acadêmico que três alunas de Pedagogia em EAD demonstram na elaboraçăo de seus Trabalhos de Conclusăo de Curso. Além disso, procura-se verificar como a universidade se prepara para a oferta de seus cursos nessa modalidade: de um lado para desenvolver o letramento acadêmico de seus alunos e, por outro, evitar possíveis plágios. Na grade curricular do curso nâo há previsâo de atividades acadêmicas que preparem os alunos para a escrita do trabalho final. Consequentemente, as alunas, com uma concepçâo equivocada do que seja um trabalho acadêmico e, para fazer o que a universidade lhes pede, recorrem ao plágio. Antes de criminalizar a atitude das alunas, entretanto, é necessário que as universidades revejam práticas de leitura e escrita, de modo especial na modalidade EAD e se preocupem com a qualidade dos cursos que ofertam.
\end{abstract}

Palavras-chave: Escrita Acadêmica. Plágio. Ensino a Distância. Formaçăo de Professores.

ABSTRACT: A growing demand for teacher training programs has led to an increase of distance learning programs in education, which have become the main type of undergraduate programs in education. Within this group, Pedagogy has the most number of subscribers. Our aim is to identify the academic work concepts he demonstrated by three Pedagogy students in the preparation of their honors thesis in distance learning. Additionally, we evaluate how the university is preparing itself to

41 Os dados discutidos neste artigo sâo parte da dissertaçâo de mestrado do segundo autor

42 Professora do Programa de Pós-Graduaçấo em Linguística Aplicada da Universidade do Vale do Rio dos Sinos-UNISINOS. E-mail: dorotea_fk@hotmail.com

43 Mestre em Linguística Aplicada pela UNISINOS, professor da Universidade Estadual do Maranhăo. E-mail: nandouema72@gmail.com 
offer its courses with this method: first to develop the academic literacy of its students and, second to avoid possible plagiarism. In the curriculum of the course there are no academic activities predict to prepare students for writing their honors thesis. Consequently, the students, with a misconception of what an honors thesis means and to do what the university requires, they resort to plagiarism. Before criminalize the student's attitude, however, it is necessary for universities to review their reading and writing practices, especially in distance education method, so that they are concerned about the quality of the courses they offer.

Keywords: Academic Writing. Plagiarism. Distance Education. Teacher Training.

\section{INTRODUÇÃO}

Se, a partir dos anos sessentas do século passado, com a democratizaçâo do ensino da escola básica, começa a mudar o perfil dos alunos, o que se vê nas duas primeiras décadas deste século é a democratizaçăo do acesso ao ensino superior, por meio de políticas públicas (como REUNI, PROUNI, FIES, ${ }^{44}$ dentre outros programas) ou mesmo pela proliferaçăo de instituiçóes de ensino superior (muitas de qualidade discutível). Aumentam ainda as ofertas de cursos superiores na modalidade de ensino a distância (EAD), também em instituiçôes públicas, como veremos adiante. Isso muda também o perfil do aluno que chega ao ensino superior, e ele deveria, pois, receber uma atençâo diferenciada. Os currículos dos cursos deveriam prever uma oferta que desse conta de atender a esse novo perfil de alunos.

Os alunos que saem da escola básica e estariam, teoricamente, prontos para continuar seus estudos no ensino superior apresentam, todavia, muitos problemas no que se refere à produçáo escrita, o que também é amplamente divulgado pela mídia a cada realizaçáo do ENEM - Exame Nacional do Ensino Médio, quando o desempenho dos alunos nâo tem se mostrado satisfatório. Também pesquisas realizadas no Brasil (OLIVEIRA, 2009; BRANDĀO, 2013; KERSCH, 2014; ASSIS, 2015, por exemplo) e no exterior (LEA; STREET, 2014; ZAVALA 2010, por exemplo) discutem a dificuldade de estudantes e professores com a escrita acadêmica. Essa escrita exige que os alunos tenham habilidades de construir um texto, trabalhando, de forma coerente, as múltiplas vozes dos autores referenciados e a sua própria voz. Essa habilidade precisa ser ensinada para que o aluno desenvolva um letramento acadêmico sólido.

As dificuldades com a escrita acadêmica sâo ainda maiores quando os alunos sâo oriundos de contextos socioculturais onde suas habilidades de leitura e escrita e letramento básico nâo foram suficientemente desenvolvidas. E maiores ainda, acreditamos, quando esses alunos de camadas menos escolarizadas da populaçâo văo buscar um curso de pedagogia na modalidade a distância e năo recebem ali um atendimento adequado para desenvolvê-los. Neste artigo, portanto, a partir da análise de três Trabalhos de Conclusāo de Curso (TCC) de Pedagogia a Distância, de um polo de uma universidade pública do nordeste brasileiro, objetivamos refletir sobre as concepçōes do que seja

44 REUNI: Reestruturaçâo e Expansăo das Universidades Federais; PROUNI: Programa Universidade para Todos; FIES: Fundo de Financiamento Estudantil, todos programas destinados a garantir o acesso de alunos ao ensino superior. 
um trabalho acadêmico para as alunas investigadas, depreendidas pelos pesquisadores nesses TCCs, bem como verificar em que medida a universidade se prepara para a oferta de cursos em duas frentes: o desenvolvimento do letramento acadêmico de seus alunos e a atençăo para possíveis plágios.

A demanda crescente por cursos de formaçăo de professores, impulsionada pela obrigatoriedade do curso superior para atuar como professor no ensino fundamental e médio, por força da Lei $n^{\circ} 12.796 / 13$, fez com que os cursos de licenciatura a distância crescessem e se tornassem, hoje, o tipo de graduaçáo em maior número na modalidade EAD. ${ }^{45}$ Dentro desse grupo, o curso de Pedagogia é o que conta com maior número de inscritos. ${ }^{46}$ Isso se dá, a nosso ver, por essa licenciatura ser vista como um "genérico" de formaçăo de professores, um grande curso de qualificaçăo para aquisiçăo de ferramentas e métodos de como ensinar melhor, o que é uma forma simplista de compreender o papel do curso de Pedagogia. Essa licenciatura deveria ser encarada como responsável pela formaçăo daqueles que năo só vâo atuar na formaçăo dos indivíduos, mas que também văo pensar caminhos para as necessárias renovaçóes e mudanças do processo educacional brasileiro. A ideia de conceber o curso de Pedagogia apenas como formaçăo de professores, a nosso ver, é muito reducionista, e, digamos, uma ideia de senso comum. Trata-se de um campo de conhecimentos sobre a problemática educativa na sua totalidade e historicidade e, ao mesmo tempo, apresenta uma diretriz orientadora da açâo educativa, no sentido de que năo é um conjunto de regras e métodos de ensinar fechados, e, sim, uma orientaçáo a partir da qual o pedagogo pode construir novos saberes e reflexóes sobre a prática educacional. Segundo Libâneo, a pedagogia se ocupa

[...] com a formaçấo do professor que irá atuar no processo ensino/aprendizagem de crianças, com processos educativos, métodos, maneiras de ensinar, mas, antes disso, ela tem um significado bem mais amplo, bem mais globalizante. Ela é um campo de conhecimentos sobre a problemática educativa na sua totalidade e historicidade e, ao mesmo tempo, apresenta uma diretriz orientadora da açáo educativa (LIBÂNEO, 2001, p. 6).

Dada essa concepçăo que temos do que seja a formaçăo do pedagogo, maior ainda tem de ser a preocupaçăo com a maneira como essa formaçăo é oferecida, o que, a nosso ver, passa necessariamente pela linguagem, mais precisamente, que seja oferecida ao professor em formaçấo a possibilidade de experienciar a leitura e a escrita como práticas sociais, que ele possa perceber que leitura e escrita devem nos auxiliar a agir adequadamente no mundo social. Passando por essa experiência, o professor estará também capacitado a adotar esse modelo de letramento com seus alunos, quando for atuar. E os currículos das instituiçóes de ensino superior deveriam se preparar para isso.

No caso da escrita acadêmica, ela pressupôe, e até exige, que tenhamos diálogo com outros autores que pensaram nosso objeto antes de nós, os quais contribuirâo teórica e metodologicamente com nossa investigaçăo. Na atuaçăo de professor orientador e

45 É possível que a falta de infraestrutura, a desigualdade social e econômica da regiăo Nordeste acabam também influenciando para que esta modalidade seja, muitas vezes, a única possibilidade de estudo para muitos dessas localidades mais afastadas.

46 Disponíveis em: http://memoria.ebc.com.br/agenciabrasil/noticia/2013-09-17/educacao-distanciacresce-mais-que-presencial. Acesso em: 30 jun. 2015. Sobre a evoluçáo da EAD no Brasil, com dados semelhantes, conferir: 〈www.abed.org.br/congresso2013/cd/130.doc〉. Acesso em: 30 jun. 2015 
avaliador de trabalhos de conclusăo de curso de pedagogia realizado na modalidade EAD de um dos autores deste artigo, constatamos que a necessidade desse diálogo nem sempre é bem compreendida pelos alunos, ou melhor, nem sempre é bem trabalhada por eles. Se a dificuldade na escrita acadêmica já existe no ensino presencial, como mostram alguns estudos aqui discutidos, como ela se dá no ensino a distância, quando se requer uma autonomia ainda maior do aluno? Os currículos dos cursos oferecidos nessa modalidade de ensino contemplam essa preocupaçăo com a formaçăo integral do professor? Há preocupaçáo da universidade com a qualidade da escrita acadêmica e com possíveis plágios?

Pretendemos responder a essas perguntas ao longo deste artigo, que se acha dividido em cinco partes. Além desta introduçăo, na próxima seçăo, apresentamos o referencial teórico que sustenta nossa investigaçăo. Em seguida, apresentamos a metodologia que usamos para conduzir nosso estudo. Na sequência, analisamos e discutimos nossos dados para, por fim, apresentar algumas consideraçôes com que encerramos o artigo.

\section{FUNDAMENTAÇÃO TEÓRICA}

A escrita na formaçăo inicial tem sido objeto de investigaçáo de muitos pesquisadores brasileiros (por exemplo, KERSCH, 2014; BARROS, 2014; DE SOUZA, 2014; ASSIS, 2015, para citar alguns), o que reveste o tema de importância. Essas discussōes sâo decorrentes daquelas iniciadas pelos pesquisadores ligados aos Novos Estudos de Letramento (LEA; STREET, 1998; 2006; 2014; GEE, 2000; LILLIS, 2003). Já a escrita exigida nos cursos oferecidos na modalidade EAD, em que a autoria muitas vezes pode ser questionada, parece que nâo tem sido suficientemente estudada.

As práticas de letramento próprias do meio acadêmico sâo muito distintas daquelas a que o aluno estava acostumado no ensino médio. Isso, provavelmente, distancia a escrita dos acadêmicos das propostas dos professores, uma vez que a maioria deles năo tem o domínio da linguagem acadêmica, que precisa ser aprendida (e ensinada). 0 professor do ensino superior, por sua vez, parece assumir que ensinar a escrever gêneros que circulam na esfera acadêmica náo é tarefa sua e que o aluno deveria vir com essas competências e habilidades desenvolvidas. Ao focar na formaçăo de professores via EAD, o desafio parece ser maior: nem sempre as universidades que oferecem essa modalidade de ensino preocupam-se, de fato, com o desenvolvimento do letramento acadêmico de seus alunos, que precisa culminar com a escrita do trabalho de conclusâo de curso - TCC. Mas que gêneros o aluno é levado a escrever ao longo da sua graduaçấo? Os currículos dos cursos EAD parecem continuar os mesmos da modalidade presencial. Ainda que o EAD traga uma série de facilidades, como o acesso ao ensino superior de alunos de lugares mais afastados os quais, de outra forma, talvez náo tivessem a oportunidade de estudar, sua proposiçáo também deveria vir acompanhada de preocupaçăo com a qualidade da entrega dos alunos (que se seguiria à qualidade da oferta).

A democratizaçăo do acesso ao ensino iniciado nos anos 1960, no Brasil, como se mencionou antes, é uma das razôes pelas quais o perfil do professor tenha mudado: já nâo apenas săo os filhos das famílias letradas que chegam ao ensino superior. Também os filhos das classes populares - às vezes provenientes de famílias pouco letradas -, muitos deles apoiados por iniciativas e incentivos governamentais (REUNI e PROUNI, 
por exemplo) agora frequentam o ensino superior, muitos deles nos cursos de licenciaturas. A fragilidade da educaçăo básica frequentemente é perceptível quando chegam ao ensino superior. Esse cenário, entretanto, năo se restringe apenas ao Brasil. Essa realidade é identificada também em outros países, em que o perfil dos alunos do ensino superior também mudou: seja pelo acesso das minorias étnicas e linguísticas, seja pelas facilidades de mobilidade promovidas pela globalizaçấo. Lillis (2003), por exemplo, argumenta a favor de uma escrita dialógica, em que o feedback dê lugar ao talkback, ou seja, a partir da escrita do aluno teria de se instaurar um verdadeiro diálogo do professor com o texto do aluno, do aluno com a escrita do professor, numa cadeia que se estenderia para além dos objetivos da disciplina. Produçấo escrita, entendida como letramentos acadêmicos (LEA; STREET, 2014), nâo significa escrever para a universidade, mas para a vida. Essa concepçăo de escrita como diálogo, no nosso entender, faria toda a diferença, principalmente na modalidade EAD, em que as tecnologias da informaçâo e comunicaçâo (TICs), se bem usadas, poderiam promover um diálogo permanente entre professor e alunos.

Evidentemente, mais perceptíveis parecem ser as lacunas na formaçăo relacionada à escrita acadêmica quando formos olhar mais de perto a formaçăo oferecida num curso de pedagogia a distância de um polo de uma cidade no interior de um estado do nordeste brasileiro: alunos vindos de contextos sociais em que a leitura e a escrita nâo organizavam a vida da família, pais muitas vezes ainda analfabetos, primeira pessoa da família a alcançar o ensino superior, pouca familiaridade com as TICs. Entretanto, se nos afiliamos aos estudos de letramento, concebendo leitura e escrita como práticas sociais, somos desafiados a abandonar a classificaçâo da escrita desses alunos apenas em boa ou má, alimentada pelo discurso do déficit (HENDERSON; HIRST, 2007). Adotar essa concepçăo de leitura e escrita nos leva a tentar compreender como chegaram às concepçóes de escrita que os pautam, ou melhor, em que medida a universidade está de fato preocupada com o desenvolvimento de seu letramento acadêmico.

Se quisermos compreender a escrita e outras práticas de letramento que acontecem em contextos acadêmicos, é necessário nos voltarmos aos estudos de Lea e Street (2006; 2014), que compreendem que essas práticas seriam concebidas a partir da "sobreposiçăo de três perspectivas ou modelos: (a) modelo de habilidades de estudo, (b) modelo de socializaçăo acadêmica e (c) modelo de letramentos acadêmicos" (LEA; STREET, 2014, p. 480).

O modelo das habilidades de estudo entende o letramento universitário como um conjunto de habilidades e ferramentas, práticas e cognitivas, que o aluno deve adquirir para conseguir integrar esta realidade de modo positivo. Quem se filia a esse modelo entende que, de posse dessas habilidades, o aluno as transferirá a quaisquer contextos de escrita. Nesse caso, a responsabilidade pelo fracasso fica somente sobre o aluno.

No modelo de socializaçáo acadêmica, a responsabilidade se inverte, e cabe ao professor a iniciaçăo do aluno nesse conjunto de habilidades específicas que o mundo acadêmico exige, familiarizando-o com os gêneros que circulam na esfera acadêmica. Nessa perspectiva, além de transferir parte da responsabilidade para o professor, esse modelo pressupóe que os gêneros discursivos acadêmicos săo homogêneos, e, uma vez adquiridas as características, o aluno seria capaz de transitar livremente por qualquer disciplina e por qualquer desafio da construçăo textual acadêmica. 
O modelo dos letramentos acadêmicos, por sua vez, parte da premissa de que leitura e escrita sáo práticas sociais, de que lemos e escrevemos para 'fazer coisas', para agir no mundo. Nessa concepçâo, o aluno deve apreender o domínio dos diversos gêneros linguísticos que possibilitarăo sua inserçăo nas diversas disciplinas. Esse modelo está relacionado à produçăo de sentido, às identidades, ao poder e à autoridade. Ao se trabalhar nessa perspectiva, tanto alunos, professores, como a própria Universidade dividem a responsabilidade acerca da construçăo deste tipo de conhecimento. O letramento acadêmico irá focar os diferentes significados que cada um deles dá à escrita. E, como prática social, leva em consideraçăo, também, a história de vida dos alunos, seus processos de letramento anteriores e sua nova realidade, quando é imerso nesse novo contexto cultural, o da Universidade.

Em relaçăo à esfera acadêmica, cabe ao aluno, segundo Oliveira (2014, p. 7), assumir "a identidade acadêmico-científica para melhor se inserir". Entretanto ele precisa ser iniciado no discurso acadêmico, o que năo ocorre facilmente, tendo em vista ser um novo discurso que deve ser aprendido, uma nova linguagem social que precisa ser apre(en)dida, que náo apenas forma, mas transforma, leva o aluno a construir novas identidades, ou, como disse uma participante da pesquisa de Stein (2016): "Eu nấo sou essa escrita aí e, ao mesmo tempo, essa escrita é minha!", quando, ao falar sobre uma resenha que produzira, no semestre seguinte já năo a identificava como sendo sua, ainda que soubesse que era.

Parece-nos que as dificuldades que os alunos encontram com a linguagem acadêmica poderiam ser suavizadas com uma mudança dos professores no trabalho em conjunto com os alunos. Escrita precisa estabelecer o diálogo. É preciso, todavia, que também os projetos acadêmicos dos cursos assumam o trabalho com os letramentos como crucial em seus currículos.

Letramentos se relacionam a relaçōes de poder, em cujo seio se forjam as identidades. Street (2013) associa o letramento aos contextos culturais, ou seja, podemos inferir que, dependendo da comunidade em que o aluno se acha inserido, letramento começa antes da escola. O letramento acadêmico, por sua vez, se inicia (ou deveria iniciar) muito antes da entrada na Universidade. Araújo e Dieb (2013) afirmam que as dificuldades de escrita no ensino superior poderiam ser decorrentes do fato de que "poucos săo os gêneros de texto com os quais os estudantes conseguem estabelecer uma comunicaçáo satisfatória, especialmente se o que estiver sendo analisado for o estilo da escrita e a organizaçăo retórica do próprio gênero". E isso precisa ser ensinado, tanto na escola quanto no ensino superior: os alunos precisam ser levados a se conscientizarem de que a escrita serve para agir no mundo social, é necessária 'fazer coisas'. E aqui concordamos com Araújo e Dieb (2013) de que, provavelmente, a atividade de escrita "tenha deixado de ter ou, quiçá, nunca tenha tido um significado (importância, valor, sentido) sensível e concreto para a vida desses sujeitos". A escrita năo tendo sentido para os sujeitos, ou năo sendo compreendida como necessária para agir no mundo, no nosso entender, é porta aberta para o plágio.

Várias de nossas práticas cotidianas sofreram (e continuam sofrendo) mudanças em funçấo da facilidade de acesso à tecnologia, o que impacta também as práticas acadêmicas. Essa facilidade de acesso, aliada à grande disponibilidade de textos e informaçōes, encontra terreno fértil para o uso da cópia. Já encontramos referência à geraçấo "Copy-Paste" ou "Crtl c + Crtl v" (ABRANCHES, 2008; SILVA, 2008), em todos 
os níveis de ensino, mas é no ensino superior (graduaçăo e pós) que ele começa a ser criminalizado. $O$ entendimento equivocado do que seja efetivamente pesquisar (e escrever) pode levar o aluno a um procedimento também equivocado (e condenado em nossa cultura): o plágio.

Para Hafernik et al. (2002, p. 43), plágio diz respeito ao uso inapropriado de fontes em trabalhos escritos para a academia, que pode envolver "copiar passagens de uma fonte sem uso de aspas e citaçăo; parafrasear sem o uso de citaçăo; apresentar ideias como sendo originais quando elas sáo tomadas de outra fonte; ou mesmo entregando um artigo que tenha sido escrito inteiramente por outra pessoa". Investigando a prática do plágio no ensino de inglês como segunda língua nos Estados Unidos, os autores sugerem que há diferenças na compreensăo do que se considera plágio na cultura ocidental em relaçâo a outras culturas. Entendem também que essa prática pode ser compreendida pelos professores ao longo de um continuum, em três estágios: no primeiro, esse comportamento é considerado sempre um erro. No segundo, os professores continuam encarando-o como erro, mas creem que as crenças e diferenças culturais de alguns alunos, distintas das suas em relaçăo ao plágio, fazem com que năo considerem seu ato como algo errado. Por último, os professores (ainda que um número pequeno) ainda creem que é errado, mas a compreensâo de diferenças culturais os faz questionar se a condenaçấo do plágio é, de fato, correta.

Compreender o que leva um aluno a plagiar é, de fato, um desafio. Celani (2005, p. 118) diz que a questâo cultural náo pode ser ignorada, e que, no contexto brasileiro, năo se pode "tomar como dado que todos os alunos têm a mesma cultura porque sâo brasileiros", com o que concordamos. Também nossos alunos, dependendo de sua formaçăo prévia, da forma como sempre lidaram com a pesquisa desde a escola básica, podem ter um entendimento diferente do nosso quando nos entregam um texto copiado, por exemplo, da internet, náo considerando que estejam fazendo algo errado. Essa discussáo precisa ser feita quando se trabalha com escrita acadêmica, uma vez que, provavelmente, năo foi feita antes de o aluno ingressar no ensino superior. Como bem lembra Celani (2005, p. 118), "o trato com os livros e outras fontes poderá ou náo ter feito parte de sua escolaridade anterior e, na maioria das vezes, os aspectos éticos referentes ao tratamento da informaçăo proveniente de fontes diversas nâo lhes foram apresentados nem foram discutidos especificamente".

Antes de criminalizarmos a prática do plágio, que é cada vez mais frequente na academia, temos de nos perguntar que espaço os currículos dos nossos cursos têm dado para discutir essa questăo. Araújo e Dieb (2013), ao analisarem como a interaçâo num fórum virtual pode alavancar a aprendizagem da escrita de textos acadêmicos e promover a construçáo de uma consciência deontológica inerente a essa atividade, destacam que uma das principais preocupaçóes dos alunos era como deveriam referir os autores consultados em seus trabalhos e, dessa forma, citá-los adequadamente, sem que isso configurasse plágio. Abrindo a discussāo da questăo no fórum, os autores mostram que:

[...] o fortalecimento da consciência dos alunos acerca da dimensáo ética que perpassa essa atividade interativa mostrou-se igualmente necessário, devendo esse fortalecimento basear-se na construçáo e na vivência de valores socialmente estabelecidos, aceitos e praticados pelos membros da comunidade acadêmica (ARAÚJO; DIEB, 2013, p. 86) 
Ou seja, quando se trabalha na perspectiva dos letramentos acadêmicos, entendidos aqui como todas as práticas de leitura e escrita de gêneros que circulam na esfera acadêmica - resumos, resenhas, artigos, ensaios, TCC, por exemplo - é preciso que os alunos sejam năo apenas familiarizados com esses gêneros, mas que lhe sejam oferecidas oportunidades reais de escrita, e que eles sejam também apresentados à cultura acadêmica, em que o plágio năo é aceito. Eles precisam aprender a resumir, parafrasear, citar, mas também precisam saber que existem leis que protegem a propriedade intelectual. E esta é a tarefa das universidades: levar os alunos a experienciar a escrita como algo natural, que eles fazem dentro e fora da universidade (mas que na universidade é um tipo específico de escrita) como necessária para produzir sentido. A partir da escrita dialógica, em que feedback acompanha talkback, o aluno poderá se apropriar das regras, valores e conceitos, bem como estrutura dos gêneros que circulam na academia. Apropriando-se dessa concepçăo de escrita, certamente também desenvolverá o que Araújo e Dieb (2013) chamam de consciência deontológica sobre a produçáo textual na academia.

\section{METODOLOGIA}

Neste trabalho, refletimos sobre as concepçôes do que seja um trabalho acadêmico para três professoras em formaçáo num curso de Pedagogia, oferecido na modalidade a distância por uma universidade pública do nordeste brasileiro, bem como verificamos em que medida a universidade se prepara para a oferta de cursos nessa modalidade, tanto visando ao desenvolvimento do letramento acadêmico de seus alunos, quanto a evitar possíveis plágios. Para essa finalidade, analisamos os Trabalhos de Conclusâo de Curso (TCCs) produzidos por essas alunas, entregues para obter o grau de pedagogo.

\section{AS AUTORAS DOS TCCS}

As alunas cujos TCC sâo objeto de análise aqui, integravam duas turmas que, originalmente, contavam com 25 alunas(os), cada uma. Quando foi iniciado o trabalho de orientaçăo em 2013, por um dos autores deste artigo, elas já estavam no sétimo período, e o número já havia sido reduzido para 11 e, destas, somente sete entregaram os Trabalhos de Conclusăo de Curso. Apenas esse dado já seria um sinalizador das dificuldades encontradas pelas alunas no decorrer do curso. Essas dificuldades, no nosso entender, estăo fortemente associadas à trajetória de letramento e de vida das alunas. Esses TCCs foram escolhidos a partir de alguns critérios: alguma pontualidade no cumprimento dos prazos e maior interaçâo com o orientador, se comparadas a outras alunas. Elas foram escolhidas, também, por representarem bem o perfil dominante do curso de pedagogia a distância da universidade em questáo: alunas que trabalham como professoras alfabetizadoras, buscando um curso superior como forma de aperfeiçoamento de suas práticas e como forma de se manter no trabalho, em funçâo de a Lei 12.796/13 determinar que todos os professores da escola básica tenham formaçâo em nível superior. O segundo autor deste artigo, pedagogo, atuava como uma espécie de 'orientador a distância', por ser o tutor, uma vez que elas também tinham um orientador presencial, o professor do curso. As orientaçōes eram realizadas pelo ambiente virtual AVA e durante alguns encontros presenciais marcados pela coordenaçăo do curso. 
Em relaçăo ao perfil socioeconômico e cultural das alunas, elas eram oriundas da zona rural de um município do interior de um estado nordestino, e integram famílias de baixa renda e com baixa escolaridade, sendo duas delas filhas de mâe e/ou pai analfabetos. Originárias do próprio município do polo em que foi realizado o trabalho de orientaçăo a distância, tiveram toda a sua formaçăo na cidade e săo, também duas delas, as primeiras pessoas da família a cursar uma Universidade.

Nas conversas informais, durante os encontros de orientaçăo, tomamos conhecimento de suas histórias de letramento e das dificuldades e faltas com que foi construída sua formaçăo superior. A partir dos relatos delas, e também na entrevista semiestruturada que fizemos com cada uma delas, fomos apresentados aos seus processos de alfabetizaçăo e letramento, na nossa avaliaçăo, malconduzidos, a suas origens familiares de baixíssima escolaridade e quase nenhum contato ou estímulo à leitura; relato de escolas de ensino fundamental e médio bastante precárias, enfim, todo um contexto social que, poderíamos imaginar, jamais as levaria ao ensino superior. Mas a oportunidade que, inegavelmente, o ensino a distância proporciona a esse público viabilizou a entrada delas na universidade. $O$ curso escolhido foi quase um processo natural: Pedagogia. Todas já atuavam como professoras alfabetizadoras antes de ingressarem na graduaçaáo e buscavam, além do diploma (agora obrigatório por força de lei), uma melhor qualificaçáo para a atuaçâo no magistério. Acreditamos que essa melhor qualificaçăo só poderia se realizar se o curso procurado por elas tivesse, de fato, uma preocupaçáo com o desenvolvimento de seu letramento acadêmico, mais precisamente de sua escrita acadêmica.

\section{O ESPAÇO DA ESCRITA NO CURSO E O FUNCIONAMENTO DA ORIENTAÇÃO}

Na grade curricular do curso de Pedagogia a Distância frequentado pelas alunas cujos TCCs săo analisados neste artigo, as disciplinas estăo divididas em três grupos: Núcleo Comum, relativas às disciplinas que trabalham conhecimentos gerais e específicos sobre o ambiente escolar e sobre a sociedade; Núcleo Específico de Aprofundamento e Diversificaçâo de Estudos, com disciplinas ligadas ao ensino na educaçăo infantil e nas séries iniciais do ensino fundamental, Ensino Médio e Núcleo Específico de Estudos Integradores, formado por disciplinas sobre a organizaçáo do trabalho escolar, incluindo a participaçăo do profissional na área de serviços e apoio escolar. Dentro desses eixos, em nenhuma disciplina se trabalha o processo de aprendizagem e desenvolvimento da escrita acadêmica, sinalizando para o fato de que este năo é um objetivo do curso. A avaliaçăo nas disciplinas era feita por meio de provas presenciais, normalmente com sete questôes: três de múltipla escolha e quatro discursivas. Chama a atençăo também que nâo eram atribuídos créditos ao TCC, ainda que o aluno fosse obrigado a construí-lo.

Em relaçâo ao trabalho de orientaçâo, essa era realizada tanto a distância como de forma presencial. No caso desta última, para esse grupo, foram três encontros com datas fixadas pela coordenaçăo, que aconteceram no polo onde as alunas estudavam/ viviam. Nesses encontros, que aconteciam em grupo, cada aluna procurava tirar suas dúvidas, e o orientador apresentava linhas gerais sobre a realizaçâo de um trabalho acadêmico, marcadamente, em relaçăo a regras e normas de escrita. A orientaçâo a distância acontecia via Moodle, com a abertura de fóruns, e por meio de mensagens 
individuais, pois era nessa plataforma que os trabalhos eram enviados ao orientador, que os corrigia e devolvia até que pudessem ser entregues. Esses dados de interaçôes escritas também săo usados nesta pesquisa.

\section{RESULTADOS E DISCUSSÃO}

Projetar e almejar uma formaçăo que desenvolva indivíduos autônomos, que sejam levados a produzir sentido com sua escrita na academia, a nosso ver, é um processo que ainda está em curso no ensino superior brasileiro, e provavelmente é mais urgente quando se olha para o Ensino a Distância. Trabalhar com EAD ainda é tarefa espinhosa, já que os desafios ligados, por exemplo, ao acompanhamento da aprendizagem do aluno sem a presença do professor ainda sâo muito grandes. A ideia de autonomia está muito ligada aos cursos de EAD, já que uma caracterizaçăo bastante frequente dessa modalidade se liga à prática do autoestudo e do gerenciamento do tempo por parte do próprio aluno. Contudo, acreditamos fielmente que um sujeito autônomo, um indivíduo socialmente pensante, ativo e participativo vai muito além disso. As Universidades, sobretudo no que se refere aos cursos superiores em EAD, precisam refletir sobre isso. No nosso entender, isso passa necessariamente pela escrita, ou melhor, pelos eventos de letramento que a universidade promove para desenvolver o letramento de seus alunos.

\section{A GRADE CURRICULAR COMO REFLEXO DO QUE A UNIVERSIDADE SUPOSTAMENTE ESPERA DOS ALUNOS}

Queremos, neste trabalho, refletir sobre as concepçōes do que seja um trabalho acadêmico para as três alunas investigadas, bem como verificar em que medida a universidade se prepara para a oferta dos seus cursos, seja em relaçăo ao desenvolvimento do letramento acadêmico de seus alunos, seja em atenção a possíveis plágios. Queremos ver como isso se manifesta a partir da análise de três Trabalhos de Conclusáo de Curso (TCC) de Pedagogia a Distância, de um polo de uma universidade pública do nordeste brasileiro. Entretanto, antes de olhar para o produto final - os TCCs - é necessário lançar um olhar sobre como, teoricamente, a universidade prepara seus alunos para tal tarefa, uma vez que compreendemos que a aprendizagem se dá num continuum, sendo processual, portanto.

A universidade cujos TCCs de alunas analisamos aqui prevê que o egresso tenha como perfil: uma "visăo crítica e um domínio de conhecimentos específicos com vistas a desenvolver competências e habilidades relativas à docência na educaçăo infantil, nas séries iniciais do ensino fundamental e nas disciplinas pedagógicas a nível médio, como afirmam as Diretrizes Curriculares para o Curso de Pedagogia". Como se vê, quem concebeu o curso nâo pensou que a "visăo crítica" e o "domínio de conhecimentos específicos" pudesse se dar por meio da linguagem, pela leitura e pela escrita. Nenhum dos três eixos da formaçăo prevê o desenvolvimento da escrita dos alunos. Além disso, verifica-se, analisando a grade curricular do curso, que nâo sâo atribuídos créditos à confecçăo do TCC, o que já nos dá indícios da importância que é atribuída à pesquisa e à escrita nesse curso. ${ }^{47}$ Sabe-se que cursos na modalidade EAD săo ‘bom negócio', porque

47 Náo encontramos a explicaçáo por que o TCC náo contava créditos. Os alunos eram informados de que deveriam fazê-lo, e o faziam. Recentemente, o curso passou por revisáo e, na nova grade, segundo informaçấo, serâo atribuídos créditos ao TCC. 
atendem a massas. Massa que, neste caso específico, está alijada do desenvolvimento de habilidades que vai necessariamente ter de mobilizar em seu futuro (e atual) profissional. Se a universidade năo se preocupar com que os professores tenham bem desenvolvidas suas capacidades de leitura e escrita num nível mais abstrato, como é o caso da escrita acadêmica, quem o fará?

Se alguém provém de um ambiente cultural iletrado, de uma família de baixa escolaridade, se nunca foi apresentado e nem passou perto de interagir com o discurso acadêmico, como esperar que, por um passe de mágica, esse alguém consiga produzir gêneros que circulam nessa esfera? Os estudos sobre letramento acadêmico têm demonstrado, como afirma Zavala (2010), que a linguagem e a escrita acadêmica năo săo neutras. $\mathrm{O}$ que observamos săo alunos empreendendo muito esforço para conseguir se integrar a este meio, da forma como acham que é a correta, já que provavelmente ninguém lhes ensinou isso. A integraçâo ou interaçăo com qualquer meio gera aquisiçôes que se integram às identidades do sujeito. Mas, quando essa interaçâo năo acontece e nâo gera a integraçâo, como é possível construir identidades acerca disto? Se as orientaçôes, como vimos na seçáo destinada à metodologia, se reduziam à expressăo escrita, sem atençấo à produçâo de conhecimento e sentido, que motivaçôes terăo os alunos para produzir o produto final da sua graduaçăo? Os alunos, nesse caso, podem sentir como se nâo existissem:

Muitos estudantes concebem este letramento acadêmico como uma espécie de "jogo" que lhes pede que assumam uma identidade que "năo sou eu" e que năo reflete a imagem que têm de si mesmos. Portanto, os conflitos e mal-entendidos que emergem entre estudantes e formadores em relaçáo ao tema do letramento acadêmico năo se restringem simplesmente à técnica da escritura, às habilidades ou à gramática, mas a aspectos que estấo relacionados com a identidade e a epistemologia. (ZAVALA, 2010, p.74)

Para Zavala (2010, p.76), a universidade náo é clara quanto ao que espera dos alunos. Nas regras e modelos que impóe deixa transparecer que os gêneros que circulam em seu domínio săo neutros, quase "naturais". No nosso entender, parte também do princípio de que os alunos já dominam todos os gêneros, nâo considerando o contexto sociocultural donde a maioria deles provém (muitos, por exemplo, concluem a escola básica por meio da Educaçăo de Jovens e Adultos, modalidade em que também năo é possível desenvolver todas as competências e habilidades que serăo requeridas dos alunos ao ingressarem no ensino superior). Isso provoca dificuldade para os alunos e gera, a nosso ver, um sentimento de inadequaçâo, nâo pertencimento, ou uma certeza de que eles nâo possuem a capacidade de produzirem o discurso esperado pela academia.

Há que se considerar, também, que a tarefa de ensinar a escrever é compromisso de todas as áreas, assim, isso poderia ter sido oportunizado ao longo de toda a graduaçấ, em cada disciplina ofertada. Todavia, se olhamos a grade curricular do curso, percebemos que năo há nenhuma disciplina ou atividade acadêmica voltada especificamente ao desenvolvimento do letramento dos alunos. Tampouco no âmbito das próprias disciplinas isso era oportunizado. Como dissemos acima, a avaliaçăo se dava por meio de provas e, como tal, sem a possibilidade de feedback, quanto mais talkback. Se o aluno nâo puder analisar seus erros, dialogar com seus textos e com o professor e seus textos, como vai desenvolver as habilidades de que necessitará para, posteriormente, avaliar adequadamente o que seus alunos produzirem? 
Para Zavala (2010), as dificuldades que os alunos sentem ao entrar em contato com o discurso acadêmico năo estăo ligadas apenas a questóes linguísticas, ainda que esta seja a principal preocupaçăo, como vimos antes. Também năo é uma questăo de forma, ou de ABNT. É preciso que o contexto cultural do qual os alunos provêm seja observado. Se os alunos que chegam aos cursos superiores nunca tiveram contato com a linguagem acadêmica, teráo dificuldades em reproduzi-la. Segundo Zavala, isso se deve ao fato de que nos tornamos letrados observando outros membros do discurso e interagindo com eles, até que as formas de falar, atuar, pensar, sentir e valorizar comuns a esse discurso se tornem naturais. (ZAVALA, 2010, p. 73).

Acima de tudo, escola e Universidade precisam rever seus pressupostos. Nas escolas, mas, sobretudo, nas universidades em que, nos últimos anos, se tem presenciado a entrada de alunos oriundos de ambientes e contextos culturais cada vez mais diversos, é preciso desenvolver uma forma de diálogo, onde o saber acadêmico seja apresentado aos alunos despido de uma "naturalizaçăo", ao mesmo tempo em que seja levada em conta toda a bagagem cultural dos alunos. Propomos, aqui, no fundo, a partir da concepçáo de trabalho acadêmico das alunas do curso de Pedagogia a distância, uma revisấo ou, pelo menos, um exercício de reflexăo sobre o ensino que é oferecido pelas modalidades a distância. A finalidade desses cursos deveria ser, efetivamente, uma opçâo para quem mora em lugares afastados dos grandes centros buscarem sua formaçăo em nível social, promovendo a inclusâo social desses indivíduos, e nâo a formaçâo em grande escala. O que os dados que aqui analisamos mostra o investimento do dinheiro público em alunos que, por náo saberem o que a universidade espera exatamente deles, acabam desistindo, e outros concluindo seu curso superior sem ter ideia exata do que seja produzir um trabalho final, resultante de uma pesquisa, para receber um título, ainda que nem conte créditos.

\section{O QUE OS ALUNOS IMAGINAM QUE A UNIVERSIDADE ESPERA DELES}

Se um dos poucos momentos do curso em que o aluno procura aplicar o que aprendeu ao longo dele é no TCC, mas ninguém está, de fato, interessado no que ele escreveu, fica difícil o aluno assumir a palavra como sua e desenvolver sua autonomia. O TCC para essa universidade parece ser somente mais uma tarefa. A universidade năo está interessada em saber as descobertas que o aluno fez com sua pesquisa, mesmo que essa pesquisa se resuma a tirar algumas coisas da internet e construir 'uma colcha de retalhos'. É o único jeito de pesquisar que essas alunas talvez conheçam, ainda que, sobre nossa perspectiva, esse comportamento possa ser considerado pouco ético. Como bem destaca Celani (2005), o fato de serem todas brasileiras, năo as faz pertencentes à mesma cultura que é privilegiada na academia, e "os procedimentos que consideramos como náo éticos na nossa cultura acadêmica pautada em padróes ocidentais podem năo ser percebidos como tal por alunos que năo foram expostos a esses parâmetros explicitamente" (CELANI, 2005, p. 118).

A leitura e a escrita talvez náo têm para elas o mesmo papel que nós atribuímos. Sua concepçăo de pesquisa provavelmente também năo coincide com a nossa. Ao longo de sua escolarizaçăo, a relaçăo com os livros e outras fontes pode náo ter sido suficientemente construída, e "os aspectos éticos referentes ao tratamento da informaçâo proveniente de fontes diversas náo lhes foram apresentados nem foram discutidos 
especificamente" (CELANI, 2005, p. 118). Esse parece ser o caso do curso de Pedagogia em EAD que as participantes da pesquisa frequentaram: das 37 disciplinas que o curso oferece, apenas três podem estar ligadas ao trabalho com a linguagem (Alfabetizaçấo; Fundamentos e Métodos de Ensino da Língua Portuguesa, e Língua Brasileira de Sinais - LIBRAS), mas năo necessariamente para conduzi-las à escrita do seu TCC. Entretanto, até onde se percebeu, isso nâo aconteceu, uma vez que a avaliaçấo era feita por meio de provas, como se disse antes, normalmente com sete questōes - três de múltipla escolha e quatro discursivas.

Nâo se pode dizer que os alunos nâo receberam orientaçâo para a facçâo de seus trabalhos. Via Moodle, por exemplo, o professor forneceu a estrutura do trabalho, como mostra a figura 1:

Figura 1 - Orientações quanto à estrutura do trabalho

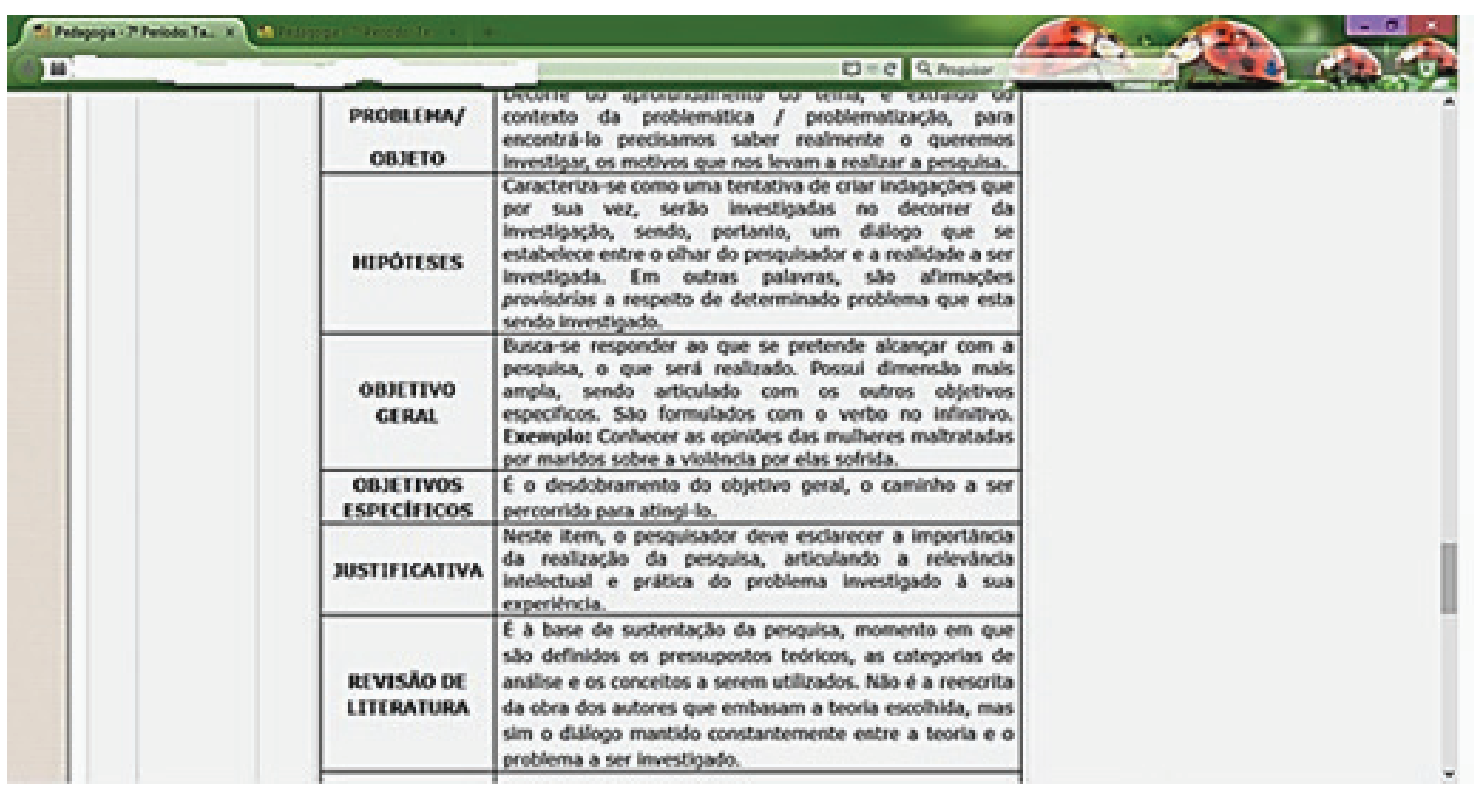

A figura 1 é um exemplo clássico do que acontece quando o professor é pautado por um modelo de letramento que năo ultrapassa a concepçâo de 'habilidades de estudo' (LEA; STREET, 2014). Parece que, se dissemos aos nossos alunos que a 'revisâo da literatura é a base da sustentaçăo de nossa pesquisa', já fizemos nossa parte, 'ensinamos', tal como na educaçâo bancária (FREIRE, 2005) - depositamos, e o aluno devolve. As alunas em questăo, entretanto, sequer passaram pelo modelo de 'socializaçáo acadêmica' (LEA; STREET, 2014), em que fossem familiarizadas com o gênero, lendo e analisando vários TCCs, para experienciar o que significa, por exemplo, 'definir pressupostos teóricos, categorias de análise e conceitos a serem utilizados'. As alunas sabiam o que săo ‘pressupostos teóricos' e 'categorias de análise'? Provavelmente nâo.

Do mesmo modo, o diálogo que o professor tutor tenta estabelecer com as alunas liga-se sempre a aspectos mais formais. 
Figura 2 - Tentativa de diálogo do tutor com a aluna

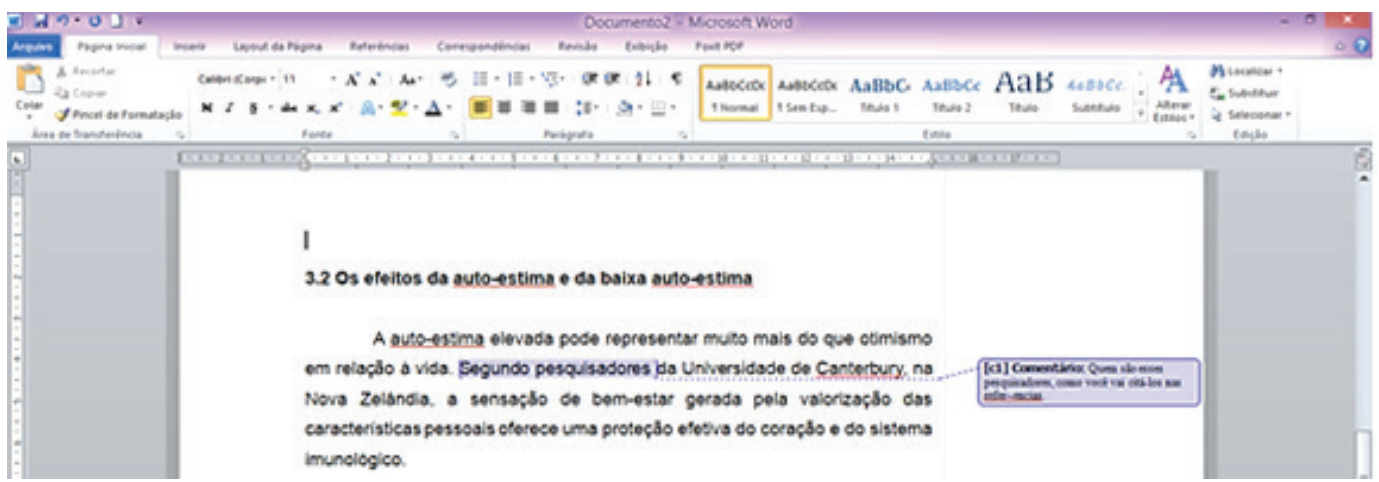

Como se vê na figura acima, o tutor tenta iniciar um diálogo sobre o texto, mas se atém mais a aspectos formais: a aluna menciona pesquisadores, preocupando-se em como ela vai citá-los nas referências, sem contudo se preocupar com o parágrafo seguinte, que tem sérios problemas de textualidade:

Figura 3 - Parágrafo que passou despercebido

\begin{abstract}
Nắo ter consciência do próprio valor. O que chamamos de baixa auto: estima. Esse é um dos motivos mais frequentes de conflitos. Quem nẫo tem consciência de seu valor como pessoa pode sentir dificuldades em qualquer outra área. Podendo levar a acredită que năo consegue nada na vida. Pois bem, isso pode ocorrer quando a pessoa só reconnece seu valor perante 0 cargo que ocupa, 0 poder que exerce, se perde isso, sente como se todo seu valor fosse perdido. É preciso ter consciência do próprio valor independente do que se tem ou do que se faz, mas valor como ser humano, independente de cargo, conta bancária, poder,
\end{abstract}

O que se observa, após o parágrafo em que o tutor chamou a atençấo da aluna a respeito de um dado que poderia nâo ser seu, encontramos uma sequência de frases fragmentadas da qual o tutor năo chama a atençáo. Se o curso oferecesse a oportunidade de feedback e talkback, aqui seria o momento de o professor/tutor parar o que estava fazendo e chamar a atençáo das alunas a respeito da estrutura da frase, a respeito da necessidade de frases bem-construídas para a construçăo de sentido. Para essas questóes que năo săo de superfície, parece năo ter havido espaço no currículo. E será que há em outros cursos de pedagogia a distância? Quando, em qualquer nível de ensino, o professor quer, de fato, saber o que o aluno tem a dizer? E aqui, parece-nos, está o segredo de um ensino de qualidade: somente se verâo mudanças no ensino, seja o nível que for, quando diminuirmos a relaçăo hierárquica que separa professor e alunos e quando quisermos efetivamente ouvir/ler o que os alunos têm a nos dizer. E isso passa pelo trabalho com projetos, como já temos mostrado em outros trabalhos (KERSCH; GUIMARÂES, 2012; KERSCH; MARQUES, 2016, por exemplo)

Ainda que, na plataforma Moodle, o tutor chamasse a atençâo das alunas: "análise essa citaçăo conforme a $A B N T$ ', ou 'lembre-se o seu texto năo deve ser apenas uma 
cópia do que vários autores falaram sobre determinado assunto', ou ainda 'analise as normas da ABNT sobre referências e verifique se os autores citados no texto estâo nas referências, pesquise outros autores também", isso năo foi suficiente para que elas produzissem textos em que realmente estivessem tentando produzir conhecimento, como designers de conhecimento (KERSCH; MARQUES, 2016). O que se teve como resultado final foi cada uma delas assumir seu papel de tarefeira (KERSCH; MARQUES, 2016) e se ver logo livre dessa tarefa. E malfeita: todas, ${ }^{48}$ em maior ou menor grau, cometeram plágio. Esta era a concepçăo de pesquisa que as formou/formatou: pesquisar é copiar trechos daqui e dali, depois se formata, atendendo as normas da ABNT, e tem-se um TCC. E isso é tăo sério que, por exemplo, o trecho abaixo, ao qual o tutor acrescentou um comentário, se jogado no Google, aparece em dois outros textos na internet.

"A auto-estima elevada pode representar muito mais do que otimismo em relaçáo à vida. Segundo pesquisadores da Universidade de Canterbury, na Nova Zelândia, a sensaçâo de bem-estar gerada pela valorizaçâo das características pessoais oferece uma proteçâo efetiva do coraçâo e do sistema imunológico."

Cada um o usa como se fosse seu, sem pruridos. Brincando um pouco com o conteúdo dos três TCCs, a próxima frase, jogando-a no Google, é encontrada presente, tal e qual, em pelo menos, outros cinco trabalhos disponíveis na internet:

"Com base nos estudos de Vygotsky (1991), observa-se que ele considera o ato da brincadeira extremamente importante para o desenvolvimento da criança."

Estamos de fato, em novos tempos, em que novos letramentos săo necessários. Novas habilidades săo exigidas dos professores, se estamos efetiva e definitivamente comprometidos com a educaçâo de nosso país. Incomoda-nos que os alunos nos 'desrespeitem' nos entregando uma cópia? Entăo está na hora de assumir nova postura quando o assunto é leitura e escrita. Nâo podemos simplesmente criminalizar o comportamento das alunas. Elas talvez tenham realmente feito 'o seu melhor', porque năo sabem pesquisar de outra forma, tampouco a universidade se preocupou em ensinar-lhes o que significa pesquisar, produzir conhecimento novo a partir daquele que já existe. Quando foi lhes mostrado o que é uma paráfrase e como se faz?

Barbastefano e Souza (2007) apresentam o plágio como tendo várias causas, mas, sobretudo, o atribuem à facilidade de acesso às informaçôes e às dificuldades decorrentes das deficiências no processo de letramento (de năo saberem parafrasear), além da falta confiança em seu próprio trabalho. As alunas, sob esse ponto de vista, năo entenderiam, portanto, que seus trabalhos e, logo, suas próprias ideias, seriam relevantes e dignas de serem avaliadas. Essa é uma questăo bastante profunda que, acreditamos, nos faz voltar os olhos à formaçâo básica, escolar, onde encontramos determinadas práticas que, quando juntas, produzem a banalizaçăo da cópia.

Em primeiro lugar, podemos lembrar que é prática corrente, normal, os alunos do ensino básico apresentarem trabalhos de "pesquisa" copiados de alguma fonte: antes

48 Ainda que neste artigo estejamos usando os TCCs de três alunas que chegaram ao final do curso, todas desse grupo de sete alunos, sem exceçâo, apresentaram plágio em seus textos 
eram as enciclopédias, hoje é a internet. E mesmo que o professor possa pensar que um determinado trabalho foi copiado, na maioria das vezes, ele dá nota (ou um visto) como se nada houvesse acontecido. $O$ que estamos ensinando nesse caso? Primeiro, que o "conteúdo correto" vale mais que a expressăo do aluno. Segundo, que autoria é algo sem muita relevância. Logo, desenvolve-se uma prática, que chega até a Universidade, de pouca importância ou falta do sentido na autoria intelectual ou artística de uma obra. O que importa é cumprir a obrigaçăo quase burocrática de entregar um trabalho ou uma monografia, se livrar da tarefa, e adquirir o título, ou melhor, passar para uma próxima fase. O processo de aquisiçăo de conhecimento e a capacidade da livre expressăo ficam absolutamente impedidos de serem concluídos com sucesso. Nấo podemos, pois, só punir o aluno que plagia, mas também precisamos realizar uma reflexâo sobre nossas condutas como professores. É claro que é um problema que existe, como já dissemos, desde o início da vida escolar. Mas, quando nós, professores do ensino superior, lemos um trabalho plagiado e ignoramos o fato, nós estamos perpetuando esta prática e contribuindo para banalizá-la ainda mais. Em tais casos, a cópia nâo é apenas uma violaçáo intencional de um código cultural, mas uma forma de sobreviver em funçâo das dificuldades e deficiências, o que é também discutido por Hafernik et al. (2002, p. 45). Ou seja, se o exercício da escrita (e aqui falamos da escrita como diálogo) năo é proporcionado pela universidade, tampouco lhe sâo apresentadas as regras de proteçâo da propriedade intelectual, o aluno tenderá a repetir o que sempre pautou seu jeito de fazer pesquisa: copiar, sem escrúpulos.

Se, enquanto professores, temos de dar conta dos novos letramentos, temos de abrir espaço em nossas aulas para a reflexăo sobre a prática do plágio entre graduandos e professores em formaçăo, visto que, conforme Silva (2008, p. 360), esse problema tem "tomado proporçóes críticas, pois roubar de si mesmo a possibilidade de outro pensar, da inventividade, é um preço muito caro que o sujeito tem a pagar". Todos devem ter direito à voz e vez. Cada aluno tem direito a ser iniciado nesse processo de tomar a palavra escrita e defender seu ponto de vista. Esse processo de tornar-se um produtor de conhecimento, um verdadeiro designer (KERSCH; MARQUES, 2016), precisa começar na escola, em que o trabalho interdisciplinar e com projetos seja estimulado. Nâo podemos nos contentar em apenas formar produtores de texto, mas precisamos (trans) formar os alunos em autores, em designers, que tomem a palavra, conforme Silva (2008, p. 362), caso contrário, passarâo "a seres apáticos, reprodutores de saberes produzidos por outrem, isto é, fracassados intelectualmente, plagiadores." Está nas nossas mâos, dos professores formadores de professores, a virada que precisa acontecer. Leitura e escrita na universidade precisam ser vistas na perspectiva dos letramentos acadêmicos, em que a produção de gêneros que circulam na esfera acadêmica se efetive para construir (novos) conhecimentos. Isso passa pelos modelos de letramento identificados por Lea e Street (2014): sâo necessárias, sim, as habilidades de estudo (até mesmo as normas ABNT), também năo podemos nos furtar da socializaçăo acadêmica (o aluno precisa se familiarizar com o gênero que vai produzir), mas, acima de tudo, as grades curriculares dos cursos de formaçăo de professores precisam abrir espaço para a leitura e escrita com alguma finalidade para agir no mundo, lendo, analisando e produzindo a variedade de gêneros que sâo próprios da esfera acadêmica. Ou nossos alunos continuarăo pensando que fazer pesquisa é copiar algumas coisas de livros ou internet, formatar de acordo com as normas da ABNT, colocar nome e entregar/enviar 
para o professor. E o professor continuará recebendo trabalhos que apenas cumprem uma tarefa, mas săo vazios de sentido. Que sinais estamos dando para nossos alunos sobre o significa escrever na/para a universidade?

\section{CONSIDERAÇÕES FINAIS}

Ao olhar atentamente para os TCCs entregues pelas alunas e tentar compreender sua concepçăo de trabalho acadêmico, somos obrigados a nos mover em uma direçấo contrária à da simples criminalizaçâo da cópia. Somos motivados a tentar entender por que estas alunas têm uma concepçâo de trabalho acadêmico que passa pela cópia literal de textos de outros autores. Nesse caminho, percebemos que suas dificuldades abrangem questôes muito mais amplas. Estăo relacionadas a toda a sua formaçấo, anterior ao ingresso na universidade. Aí vemos a universidade também preocupada apenas em formar, quando seu objetivo deveria ser de transformar o aluno num leitor/ produtor de gêneros variados. Ao que tudo indica, o que produziram ao longo de seu curso superior diz respeito a textos expositivos necessários para responder às questôes dissertativas. Talvez algum relatório de estágio. E aí um TCC no final do curso, que sequer contava créditos.

As alunas para cujos TCCs olhamos nunca ocuparam o lugar de autoras. Também a universidade em questăo nunca objetivou o desenvolvimento do letramento de seus alunos. Quando a universidade cobrou que elas ocupassem o lugar de autoras, elas deram seu jeito de fazê-lo. O jeito que elas encontraram para dar o que a universidade pedia delas reflete o que elas imaginam que seja produzir para/na academia. Se uma das características da escrita acadêmica é apresentar vozes legitimadas, para que elas mesmas fossem legitimadas, se suas ideias só sâo válidas se corroboradas por vozes de terceiros que já pensaram seu problema, porque năo ceder o espaço todo de vez? A universidade deu-lhes alternativa?

Pensamos que o plágio pode estar ligado também à baixa autoestima e, consequentemente, ao processo de construçáo de identidade enquanto leitor, de autor/escritor. Um leitor/autor se constrói năo só na escola, como nos diz Silva (2008, p. 363), mas no decorrer da vida, com as experiências vividas e as leituras feitas, através do processo, por exemplo, do letramento que começa bem antes da entrada na escola.

Precisamos todos, professores, escolas, universidades, repensar nossas práticas de leitura e escrita. No caso da universidade, é preciso estimular, desde os primeiros períodos, a que os alunos produzam textos próprios. Escrever é se expor, é desenvolver um estilo, uma maneira de ser, assumir um papel, construir uma identidade. E, num processo educativo que nega essa experiência, o aluno vai sempre buscar apoio nos textos já produzidos por outros, com os quais ele concorda, para que falem por ele.

Se uma das razóes pelo alastramento do plágio é a facilidade de acesso à tecnologia/ internet, talvez seja hora de tirar proveito disso, uma vez que ambas vieram para ficar. Vamos também nós navegar com mais frequência na rede de computadores e deixar claro para os alunos o que esperamos deles, trabalhando a leitura e a escrita à exaustăo. 
Terminamos este texto com as palavras de Silva (2008):

[...] as experiências vivenciadas com/no texto digital devam ser conduzidas dentro da universidade de modo que os professores, ao contrário de ignorar a apropriaçăo/ expropriação de textos, que acontece com muita frequência entre os graduandos, possam implementar açôes que venham a convergir para um novo paradigma no aprendizado e, assim, convidem o sujeito aprendente à participaçáo num processo interativo, ético, com uma dimensáo estética que já é própria da linguagem e da humanidade. 


\section{REFERÊNCIAS}

BARBASTEFANO, R. G; SOUZA, C. G. DE. XXVII Encontro Nacional de Engenharia de Produçăo, 2007, Florianópolis. Percepçăo do Conceito de Plágio Acadêmico entre Alunos de Engenharia de Produçâo e Açōes para sua Reduçăo. Anais XXVII Encontro Nacional de Engenharia de Produçăo, 2007, Florianópolis: UFSC, 2007.

BARROS, W. C. Das práticas de plágio à autonomia textual. In: PEREIRA, R. C. M. (Org.) Didatizaçăo e Construçăo de Saberes. Joâo Pessoa: Ideia, 2014.

ABRANCHES, S. P. II Simpósio Hipertexto e Tecnologias na Educaçâo: Multimodalidade e Ensino, 2008, Pernambuco. O que fazer quando eu recebo um trabalho crtl c + ctrl v? Autoria, pirataria e plágio na era digital: desafios para a prática docente. Anais, II Simpósio Hipertexto e Tecnologias na Educaçăo: Multimodalidade e Ensino, 2008, Pernambuco. Pernambuco: UFPE, 2008.

ARAUJO, J. C.; DIEB, M. Autoria e deontologia: mediaçāo de princípios éticos e práticas de letramento na escrita acadêmica em um fórum virtual. Revista Brasileira de Linguística Aplicada. v. 13, n. 1, pp. 83-104, 2013.

ASSIS, J. A. "Eu sei mas nâo consigo colocar no papel aquilo que eu sei": representaçôes sobre os textos acadêmico-científicos. In: BOCH, F.; RINCK, F.; ASSIS, J. A. (Org.). Letramento e formaçăo universitária: formar para a escrita e pela escrita. Campinas: Mercado de Letras, 2015.

CARVALHO, J. A. B. Literacia Académica: da escola básica ao ensino superior - uma visâo integradora. Revista Letras e Letras, v. 29, n. 2, pp. 1-17, 2013.

CELANI, M. A. A. Literacia Questōes de ética na pesquisa em Linguística Aplicada. Linguagem \& Ensino. v. 8, n. 1, pp. 101-122, 2005.

FREIRE, P. Pedagogia do oprimido. Sâo Paulo: Ed. Paz e Terra, 2005.

GEE, J. P. Identity as an analytic lens for research in education. Review of Research in Education, v. 25, n. 1, pp. 99-125, 2000.

HAFERNIK, J. J.; MESSERSCHMITT, D. S.; \& VANDRICK, S. Ethical issues for ESL faculty: Social justice in practice. New Jersey: Lawrence Erlbaum Associates, 2002.

HENDERSON, R. HIRST, E. Reframing academic literacy: Re-examining a short-course for "disadvantaged" tertiary students. English Teaching: Practice and Critique. v. 6, n. 2, p. 25-38, 2007.

KERSCH, D. F. O letramento acadêmico na formaçăo continuada: constituiçăo de autoria e construçáo de identidades. Desenredo. v. 10, n. 1, pp. 54-64, 2014.

:; GUIMARÂES, A. M. M. A construçăo de projetos didáticos de leitura e escrita como resultado de uma proposta de formaçăo continuada cooperativa. Revista Brasileira de Linguística Aplicada, v. 12, pp. 533-556, 2012.

.; MARQUES, R. G. Saímos do cinema de alma lavada: Multiletramentos e trabalho Interdisciplinar na produçấo de curtas de acessibilidade midiática. Trab. Ling. Aplic., Campinas, n. 55.1), pp. 77-99, jan./abr. 2016. 
LEA, M. R; STREET, B. V. Student writing in higher education: an academic literacies approach. Studies in Higher Education. v. 23, n. 2, pp. 157-173, 1998.

. The "Academic Literacies" Model: theory and applications. Theory into practice. v. 45, n. 4, p. 368-377, 2006.

LIBÂNEO, J. C. Organizaçăo da Escola: teoria e prática. Goiânia: Alternativa, 2001

LILLIS, T. Student writing as 'Academic Literacies': drawing on Bakhtin to move from critique to design. Language and Education. v. 17, n. 3, pp. 192-207, 2003.

SILVA, O. S. F. Entre o plágio e a autoria: qual o papel da universidade?. Revista Brasileira de Educaçăo. v. 13, n. 38, pp. 357-414, 2008.

SOUZA, S. C. T. de. Escrita acadêmica no ensino superior: um estudo de interlocuçôes de artigos científicos de alunos de graduaçăo. In: PEREIRA, R. C. M. (Org.) Ateliê de Letramentos Acadêmicos - Didatizaçăo e Construçăo de Saberes. Joăo Pessoa: Ideia, 2014.

STEIN, J. de Q. Eu năo sou essa escrita aí e, ao mesmo tempo, essa escrita é minha: por uma problematizaçăo enunciativa benvenistiana para o ensino da escrita. 2016. 178 f. Tese (Doutorado em Linguística Aplicada) - Doutorado em Linguística Aplicada: Universidade do Vale do Rio dos Sinos, Sâo Leopoldo, 2016.

STREET, B. Políticas e práticas de letramento na Inglaterra: uma perspectiva de letramentos sociais como base para uma comparaçăo com o Brasil. Cadernos CEDES. v. 33, n. 89, pp. 51-71, 2013.

ZAVALA, V. Quem está dizendo isso?: Letramento acadêmico, identidade e poder no ensino superior. Traduçāo de Luanda Sito e Marília C. Valsechi. In: VÓVIO, C.; SITO, L.; DE GRANDE, P. (Org.). Letramentos: rupturas, deslocamentos e repercussóes de pesquisa em linguística aplicada. Campinas: Mercado de Letras, 2010. 